\title{
Kajian aktivitas kapal pukat cincin pelagis kecil di Pelabuhan Perikanan Samudera Bitung
}

\author{
Study of small pelagic purse seiner activities in Bitung Oceanic Fishing Port \\ Fretsman KASUKARE*, MARIANA E. KAYADOE dan JANNY F. POLII \\ Program Studi Pemanfaatan Sumberdaya Perikanan, Fakultas Perikanan dan Ilmu Kelautan, \\ Universitas Sam Ratulangi, Manado 95115
}

\begin{abstract}
Activity of small purse seiner should be supported by an adequate port; on the other hand, the development of a fishing port should be used appropriately to support the overall activities of fisheries. This study aimed to examine the activity of small pelagic purse seiner in the Bitung Oceanic Fishing Port; and to assess the feasibility of facilities to meet the needs of small pelagic purse seiner. This research was conducted based on the descriptive method. Arrival and departure activities of small pelagic purse seiner 5-10 GT during the year 2013, the maximum occurs in December as many as 75 times. Maximum activity of vessel 11-20 GT occurs in July as many as 25 times. Maximum activity of vessel 21-30 GT as many as 95 times occurs in July. Ship 31-50 GT in size is usually much active on April to May; but the length of pier is not sufficient to accommodate the need of small pelagic purse seiners. Diesel fuel tank capacity of $100 \mathrm{kl}$ is still adequate to meet the needs of small pelagic purse seiners. But the production of ice blocks and water supply cannot meet the needs of small purse seiner every day yet.
\end{abstract}

Keywords: boat activities, fishing ports, purse seine, Bitung

\begin{abstract}
ABSTRAK
Aktivitas kapal perikanan pukat cincin perlu ditunjang oleh pelabuhan yang memadai, sebaliknya pembangunan suatu pelabuhan perikanan harus dapat dimanfaatkan dengan sebaik-baiknya untuk mendukung keseluruhan kegiatan perikanan tangkap. Penelitian ini ditujukan untuk mengkaji aktivitas kapal-kapal pukat cincin pelagis kecil di Pelabuhan Perikanan Samudera Bitung; dan mengkaji kelayakan fasilitas untuk memenuhi kebutuhan kapal pukat cincin pelagis kecil. Penelitian ini dilakukan berdasarkan metode deskriptif. Aktivitas keluar masuk kapal pukat cincin pelagis kecil ukuran 5-10 GT selama tahun 2013, maksimum terjadi pada bulan Desember yaitu sebanyak 75 kali. Kapal ukuran 11-20 GT, aktivitas maksimum pada bulan Juli sebanyak 25 kali. Kapal ukuran 21-30 GT, aktivitas maksimum pada bulan Juli sebanyak 95 kali. Kapal ukuran 31-50 GT banyak beraktivitas pada bula AprilMei; tetapi panjang dermaga belum mencukupi untuk bersandarnya kapal-kapal pukat cincin pelagis kecil. Tangki solar kapasitas $100 \mathrm{kl}$ masih memadai memenuhi kebutuhan kapal-kapal pukat cincin pelagis kecil. Tetapi produksi es balok dan ketersediaan air bersih belum dapat memenuhi kebutuhan kapal setiap hari.
\end{abstract}

Kata-kata kunci: aktivitas kapal, pelabuhan perikanan, pukat cincin, Bitung

\section{PENDAHULUAN}

Pelabuhan perikanan adalah tempat yang terdiri dari daratan dan perairan di sekitarnya dengan batas-batas tertentu sebagai tempat kegiatan pemerintah dan kegiatan sistem bisnis perikanan yang dipergunakan sebagai tempat kapal perikanan bersandar, berlabuh dan atau bongkar muat ikan

\footnotetext{
* Penulis untuk penyuratan; email:

fretsmankasukare@ rocketmail.com
}

yang dilengkapi dengan fasilitas keselamatan pelayaran dan kegiatan penunjang perikanan (UU No. 31 tahun 2004). Pada hakekatnya pelabuhan perikanan merupakan basis utama kegiatan industri perikanan tangkap yang harus dapat menjamin suksesnya aktivitas usaha perikanan tangkap di laut. Pelabuhan perikanan berperan sebagai terminal yang menghubungkan kegiatan usaha di laut dan di darat ke dalam suatu sistem usaha dan berdaya guna tinggi. Pelabuhan 